Article

\title{
Religious Heterogamy and the Intergenerational Transmission of Religion: A Cross-National Analysis
}

\author{
Brian L. McPhail 1
}

Department of Sociology, Purdue University, 700 W. State Street, West Lafayette, IN 47907, USA; bmcphail@purdue.edu

Received: 15 January 2019; Accepted: 11 February 2019; Published: 14 February 2019

\begin{abstract}
This study examines the effect of religious heterogamy on the transmission of religion from one generation to the next. Using data from 37 countries in the 2008 Religion III Module of the International Social Survey Programme (ISSP), I conduct a cross-national analysis of the relationship between parents' religious heterogamy and their adult childrens' religious lives. By estimating fixed effects regression models, I adjust for national-level confounders to examine patterns of association between having interreligious parents during childhood and level of adult religiosity as measured by self-rated religiousness, belief in God, and frequencies of religious attendance and prayer. The results indicate that having religiously heterogamous parents or parents with dissimilar religious attendance patterns are both associated with lower overall religiosity in respondents. Parents' religious attendance, however, mediates the relationship when each parent has a different religion. Having one unaffiliated parent is associated with lower religiosity regardless of parents' levels of religious attendance. The negative impact of parents' religious heterogamy on religious inheritance is independent of national-level factors and has implications for anticipating changes in the religious landscapes of societies characterized by religious diversity and growing numbers of interreligious marriages.
\end{abstract}

Keywords: religious heterogamy; parents; socialization; international; religiosity; religious affiliation; religious attendance

\section{Introduction}

For several decades, researchers have documented the profound and persistent influence of parents on the religious identities, beliefs, and behaviors of their children (Glass et al. 1986; Myers 1996; Sherkat 1998; Smith and Denton 2009; Bengtson 2013). Relatively little research, however, has examined the impact of religious heterogamy ${ }^{1}$ on the religious development of children, and fewer still have explored the phenomenon of religious inheritance in other societies. This study extends the study of religious socialization ${ }^{2}$ beyond the United States to conduct a cross-national investigation of the effect of religious heterogamy on the intergenerational transmission of religion. How does having interreligious parents during childhood impact an individual's later religiosity?

Prior studies in the U.S. have consistently found that parents who do not share the same religion produce less religious children than parents who do (Hoge and Petrillo 1978; Nelsen 1990; Myers 1996; Bengtson 2013). The primary question of this study is whether this effect holds across a variety of societal

1 I use the terms religious heterogamy, religious intermarriage, and interreligious marriage interchangeably to refer to marriage in which spouses do not identify with the same religion.

2 I use the terms religious socialization, religious inheritance, and the intergenerational transmission of religion interchangeably to refer to the phenomenon of children learning or adopting religious identities, beliefs, orientations, values, and/or practices from their parents. 
contexts. The answer is not inconsequential. Religiously heterogamous marriages represent a nontrivial proportion of the married populations in many nations (see Figure 1). Furthermore, interreligious marriages have been growing, not only in the United States (Glenn 1982; McCutcheon 1988; Kalmijn 1991; Lehrer 1998; Rosenfeld 2008; Putnam and Campbell 2010; Pew Research Center 2016) but also around the world (see Figure 2) (O'Leary 2001; Voas 2003). If having religiously heterogamous parents is associated with lower levels of religiosity than having religiously homogamous parents, there are important implications for anticipating and understanding changes in the religious landscapes of societies characterized by religious diversity. Because a major factor in the growth or decline of religion in a society is the effectiveness of one generation to reproduce religion in the next generation (Voas 2003; Bisin et al. 2004; Bengtson et al. 2009; Bengtson 2013), there is a need to better understand the impact of having interreligious parents on the future religiosities of children from these families.

This study extends previous research on religious heterogamy by using cross-national data from the International Social Survey Programme (ISSP) to examine the effect of interreligious marriages on the transmission of religion from one generation to the next. I contrast having religiously heterogamous parents with having religiously homogamous parents to examine patterns of association with levels of adult religiosity as measured by self-rated religiousness, belief in God, and frequencies of religious attendance and prayer. Analyses suggest that the impact of parents' religious heterogamy on religious inheritance is independent of societal-level contextual factors. This finding contributes to the larger research project of examining family factors related to generational differences in religiosity, particularly in religiously diverse societies with rising levels of religious intermarriage.

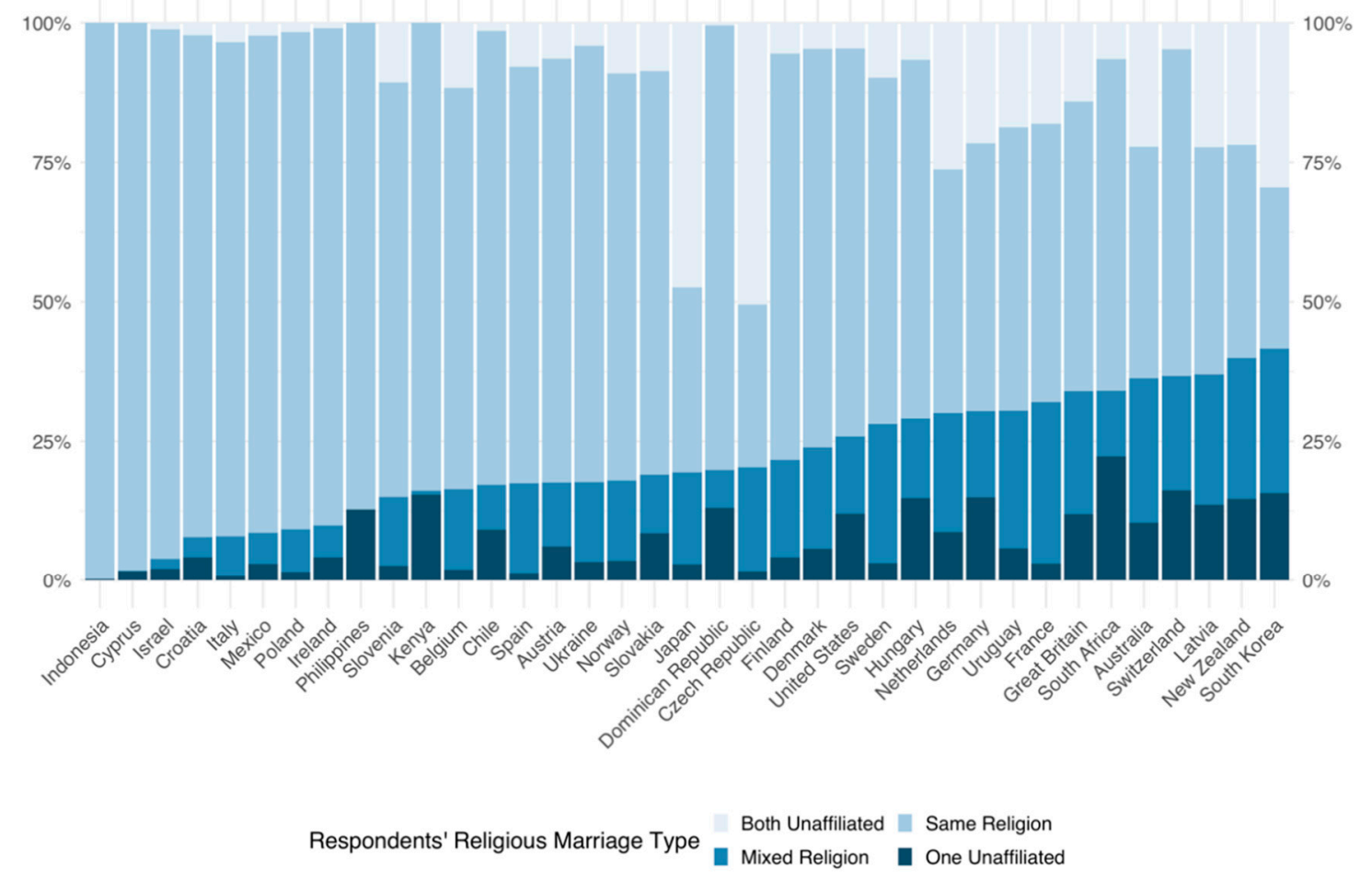

Figure 1. Percent religious heterogamy by country, ISSP 2008. 


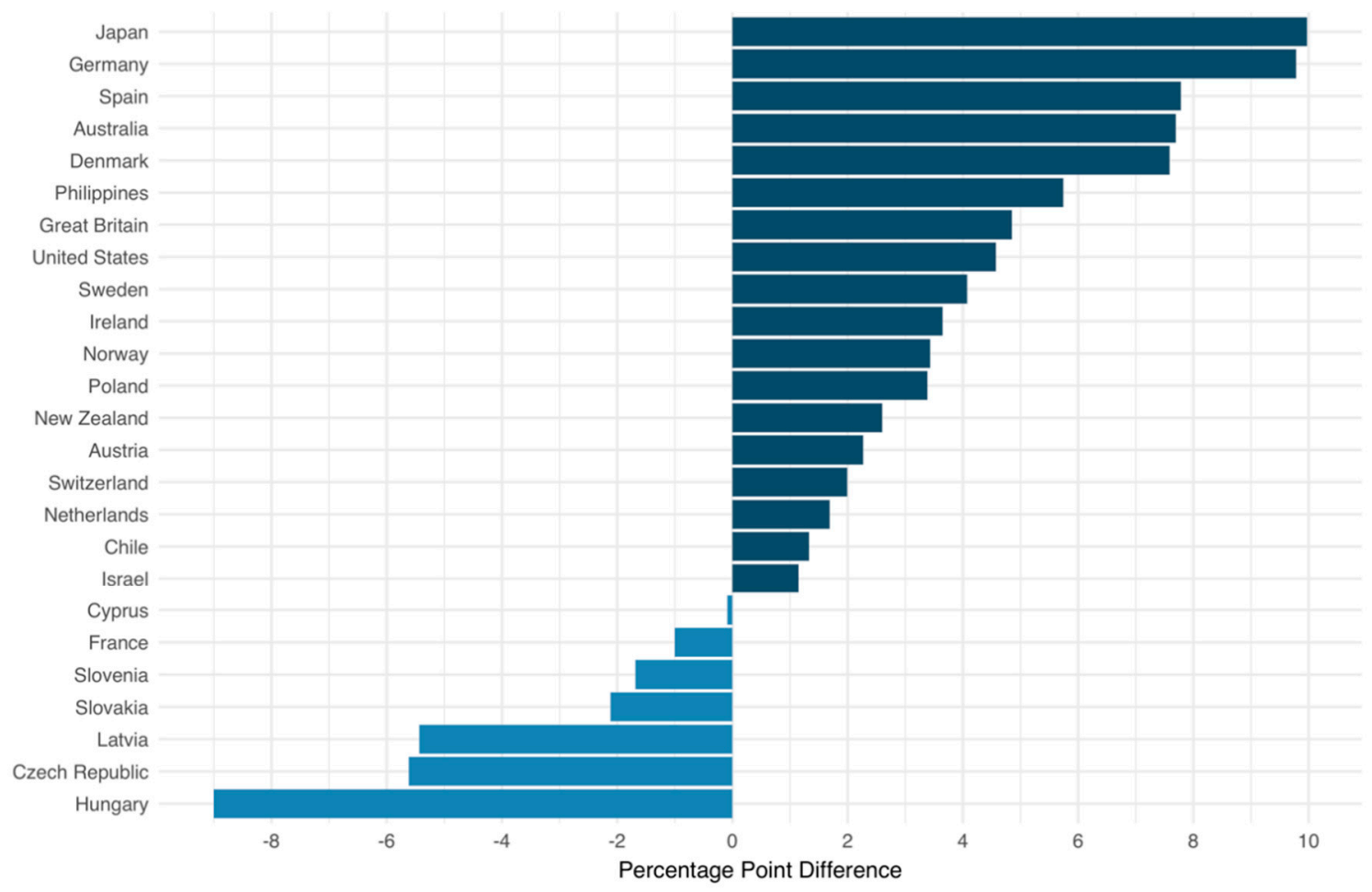

Figure 2. Percentage point change in religious heterogamy by country, ISSP 1998-2008.

\section{Conceptual Framework}

\subsection{The Intergenerational Transmission of Religion}

Parents are the most important social influence that shapes the religious lives of their children, both during adolescence and adulthood (Myers 1996; Regnerus et al. 2004; Smith and Denton 2009; Denton and Culver 2015). Other factors such as aging and life course events (i.e., marriage and parenthood), friend networks, spouse's religiosity, and recent religious experiences are also key determinants of adult religiosity (Roof and Hoge 1980; Willits and Crider 1989; Chaves 1991; Hoge et al. 1994; Wilson and Sherkat 1994; Stolzenberg et al. 1995; Regnerus et al. 2004), but parental religiosity remains the strongest predictor overall. To explain the mechanisms by which religious beliefs, values, and behaviors are transmitted, reinforced, and reproduced across generations, several major theoretical explanations exist in the literature on religious socialization: (1) Parents model religion that their children imitate, (2) parents channel their children into religious institutions, environments, and social networks where religion is reinforced, and (3) positive affective relationships between parents and children facilitate religious inheritance.

The first explanation, which stems from social learning theory, theorizes that human beings learn religious behavior primarily through modeling: children observe and imitate the behavior of others (i.e., parents) in their social context (Bandura and Walters 1977). Therefore, parents who practice religion more often or who emphasize religion in the home produce children who are more religious (Hunsberger and Brown 1984; Willits and Crider 1989; Myers 1996; Bengtson et al. 2009; Smith and Denton 2009).

The second explanation, the channeling hypothesis, claims that parents indirectly socialize their children into religion by "channeling" them into social institutions and environments where religious values are reinforced (Himmelfarb 1980). Taking children to religious services or venues, sending children to religious schools, and introducing children to peer networks are all ways that parents "channel" them into social situations where they learn religion. Several studies suggest that peer networks and religious communities have a greater influence on the religious development 
of individuals than previously acknowledged (Cornwall 1989; Erickson 1992; Martin et al. 2003; Regnerus et al. 2004).

The third explanation argues that the degree of parental affection and the quality of family relationships moderate the influence of parental religiosity on the religiosity of children. The greater the affection and the stronger the social bonds in the family, the more effective parents are at transmitting religion (Bengtson et al. 2002). The quality of the relationship between parents and children (Hoge and Petrillo 1978; Clark and Worthington 1990; Myers 1996; Sherkat 1998; Bengtson et al. 2002; Smith and Denton 2009; Bengtson 2013; Denton and Culver 2015) and between the parents themselves (Myers 1996; Lawton and Bures 2001; Regnerus et al. 2004; Copen and Silverstein 2007; Zhai et al. 2007) strongly predict the future religiosity of children.

Although most research on religious socialization has focused on factors within the family context, a few notable studies evidence the significant influence of the societal context on the transmission of religion across generations. Kelley and Graaf (1997) found that a nation's religious environment significantly impacts the effectiveness of parents' religious socialization of their children: Family religiosity more strongly influences an individual's religious life in more secular nations than in more religious nations. A follow-up study also demonstrated that national contexts with high levels of income inequality allow religion to be more easily transmitted from parents to children; however, former socialist nations increase socialization costs while nations with high economic development do not significantly impact religious socialization efforts (Müller et al. 2014).

\subsection{Religious Heterogamy}

Heterogamy commonly refers to marriage in which partners differ on some attribute (e.g., race, education). Religious heterogamy, then, implies marriage in which spouses do not identify with the same religion. This can take several forms. Spouses can either each identify with a different religion or one spouse can identify with a religion while the other does not. Some U.S.-based studies have even explored denominational heterogamy in which partners are identified as belonging to two different Protestant denominations (Curtis and Ellison 2002; Petts and Knoester 2007; Bengtson 2013). For the purposes of this international study, however, I operationalize religious heterogamy as any observation in which a respondent and his/her spouse do not identify with the same of 11 broad religion categories of the ISSP (ISSP Research Group 2012). Alternative to examining spousal differences in religious affiliation, some researchers have explored other forms of religious dissimilarity in which partners differ in other aspects of their religious lives such as religious beliefs, participation, or practices (Call and Heaton 1997; Ellison and Sherkat 1999; Curtis and Ellison 2002; Wilcox and Wolfinger 2008; Vaaler et al. 2009; Mahoney 2010).

Although religious homogamy is still predominant in most societies, religious heterogamy is increasingly common. Figure 1 illustrates the percentage of married respondents in religiously heterogamous marriages from each country in the 2008 ISSP dataset. Countries are rank ordered by the percentage of respondents that do not share the same religious affiliation with their partners, either because each partner has a different religious affiliation or because one partner is religiously unaffiliated. Of the 37 countries included, 29 have greater than 10 percent religious heterogamy and 14 have greater than 25 percent religious heterogamy. Furthermore, the phenomenon of religious heterogamy is growing, not only in the United States (Glenn 1982; McCutcheon 1988; Kalmijn 1991; Lehrer 1998; Sherkat 2004; Rosenfeld 2008; Putnam and Campbell 2010; Pew Research Center 2016) but also around the world ( $\mathrm{O}^{\prime}$ Leary 2001; Voas 2003). Figure 2 shows that among the 25 countries included in both the 1998 and 2008 ISSP Religion modules, more than half had a greater than 2.5 percentage point increase in religious heterogamy over that 10 -year period. ${ }^{3}$

3 The decreases in religious heterogamy in the Czech Republic, Latvia, Slovakia, and France since 1998 is associated with increases in the percentage of respondents reporting that both they and their spouses are both religiously unaffiliated. 


\subsection{Religious Heterogamy and the Intergenerational Transmission of Religion}

Early studies of denominational heterogamy in the U.S. found that individuals with parents who did not belong to the same religious denomination were less religious overall than individuals with parents who did (Anders 1955; Putney and Middleton 1961; Havens 1964; Hoge and Petrillo 1978). More recent studies confirm these earlier findings, showing that having religiously heterogamous parents is negatively associated with religiosity compared to having religiously homogamous parents (Nelsen 1990; Myers 1996; Bengtson 2013). Furthermore, compared to having parents who identify with two separate religions, having one parent who is religiously unaffiliated is related to even lower levels of religiousness (Nelsen 1990).

Several possible explanations can account for the relationship between parental religious heterogamy and weaker religious socialization outcomes. First, religious heterogamy is associated with lower levels of overall religiosity (Williams and Lawler 2002; Pew Research Center 2016) and less frequent religious practice among marriage partners themselves (Petersen 1986; Petts and Knoester 2007; Pew Research Center 2016). Additionally, religious intermarriage is associated with greater likelihood of eventual religious disaffiliation by one or more partners (Sherkat 1991; Voas 2003), less emphasis on religion in the home (Williams and Lawler 2002; Pew Research Center 2016), and less frequent prayer or reading of scripture with children (Pew Research Center 2016). If interreligious parents are less religious themselves, then social learning theory predicts corresponding lower levels of religiosity among their children.

Second, religiously heterogamous parents are less likely to "channel" their children into religious environments where they can learn religion. Interreligious parents report participating in fewer religious activities with their children (e.g., attending worship services) than religiously homogamous parents (Petts and Knoester 2007; Pew Research Center 2016). Recent survey evidence also indicates that they are less likely to send children to religious education activities or to a religious school (Pew Research Center 2016).

Third, interreligious couples are more likely to experience interpersonal conflict or marital instability (Myers 1996; Call and Heaton 1997; Curtis and Ellison 2002; Petts and Knoester 2007; Wright et al. 2017). These disrupt the affective bonds of the family that are believed to facilitate effective religious socialization (Bengtson et al. 2002; Bengtson 2013). Parents with greater marital happiness and marital stability produce children with higher levels of religiosity (Myers 1996; Copen and Silverstein 2007; Zhai et al. 2007). Religious heterogamy (Glenn 1982; Heaton 1984) and dissimilarity in religious attendance patterns (Heaton and Pratt 1990), however, are associated with decreased happiness and satisfaction in marriage. In addition, interreligious marriages and couples with other significant differences in religious participation or theological beliefs are more likely to experience higher levels of marital conflict (Chinitz and Brown 2001; Curtis and Ellison 2002; Petts and Knoester 2007) and are more likely to end in divorce (Heaton and Pratt 1990; Lehrer and Chiswick 1993; Kalmijn et al. 2005).

\section{Hypotheses}

The conceptual framework and prior research lead to the following hypotheses.

Hypothesis 1. Having parents who each have a different religious affiliation will be negatively associated with respondent religiosity compared to having parents who share the same religious affiliation.

Hypothesis 2. Having one religiously unaffiliated parent will be negatively associated with respondent religiosity compared to having parents who share the same religious affiliation.

Hypothesis 3. Having one religiously unaffiliated parent will be negatively associated with respondent religiosity compared to having parents who each have a different religious affiliation. 
Hypothesis 4. Having parents who attended religious services at different frequency levels will be negatively associated with respondent religiosity compared to having parents who attended religious services at the same frequency level.

Hypothesis 5. The relationship between parental religious heterogamy and respondent religiosity will be partially mediated by parental religious attendance.

\section{Data and Methods}

\subsection{Sample}

The data in this analysis come from the 2008 Religion III Module of the International Social Survey Programme (ISSP). Each year, the ISSP, which is a consortium of survey agencies in member countries, prepare a module of questions that are fielded either as an individual survey or alongside a regular national survey. For the 2008 ISSP Religion III Module, a total of 59,986 respondents ages 18 years and older ${ }^{4}$ in 40 member nations were interviewed about their religious affiliations, beliefs, practices, traditions, and attitudes. This module was also administered in four non-ISSP member countries (Indonesia, Kenya, Sri Lanka, and Tanzania) and is published as a separate dataset. To increase the representation of non-Western societies in the analysis, the data from these four countries $(\mathrm{N}=6697)$ were appended for these analyses. The sampling strategies (simple random and multi-stage stratified) and mode of data collection (face-to-face interviews, self-completed mail surveys, and phone interviews) varied by nation. For additional information on the ISSP and the 2008 Religion III Module, including sampling procedures, modes of data collection, and response rates, see ISSP Research Group (2012).

Information on key variables was not available for some respondents, because some questions were not included on the survey fielded in Portugal (urbanity), Venezuela (marital status and parents' religious attendance), Turkey (marital status), Taiwan (children in the household), and Sri Lanka (respondent's religious attendance). Additionally, more than 40 percent of respondents in Tanzania and Russia did not provide responses for parents' religious attendance. Because there is no information or not enough information on these key variables, all observations from these 7 countries were excluded from the analyses. After dropping these countries, approximately 3 percent of respondents had no mother and/or no father present in the home as a child; therefore, these were excluded as well. About 11 percent of respondents either did not know or refused to answer the survey question about the religious attendance of at least one of their parents. After the list-wise deletion of these cases with missing responses, my final analysis sample size was 41,941 from 37 nations.

\subsection{Respondent Religiosity}

The dependent variable in this analysis is a measure of the overall religiosity of the respondents, which I operationalize using a standardized scale comprised of four ISSP survey items: self-identification as religious, belief in God, and the frequencies of religious attendance and prayer (Schwadel 2015). In the ISSP self-identification as religious is measured using a 7-point index ranging from "extremely nonreligious" to "extremely religious." Belief in God is measured using a 6-point index ranging from "I don't believe in God" to "I know God really exists and I have no doubts about it." The frequencies of religious service attendance and prayer are both measured using a 9-point index ranging from "never" to "several times a week." To obtain a measure of overall religiosity, I standardized each of these variables by converting the values to z-scores, then summed them and 
standardized the total so that the overall religiosity scale has a mean of 0 and a standard deviation of 1 . Cronbach's alpha for this scale is 0.86 .

\subsection{Parental Religious Heterogamy and Religious Attendance}

In this analysis, the focal independent variables are a measure of parents' religious marriage type when respondents were children and a measure of similarity in parents' religious attendance. The first uses the religious affiliation combination of the respondents' fathers and mothers to categorize their religious marriage type. The ISSP asks respondents to indicate the religious preference of both their fathers and mothers when the respondents were children and then recodes these preferences into 11 categories: "None," "Roman Catholic," "Protestant," "Christian Orthodox," "Jewish," "Islam," "Buddhism," "Hinduism," "Other Christian Religions," "Other Eastern Religions," and "Other Religions." Using these 11 religious affiliation categories for respondents' fathers and mothers, I construct a new nominal variable in which the marriages of respondents' parents are compared and categorized into four categories: "Same Religion," "Mixed Religion," "One Unaffiliated," and "Both Unaffiliated." The "Same Religion" category is the reference group. Parents who have two different religious affiliations (Mixed Religion) and parents in which one is religiously unaffiliated are both a form of parental religious heterogamy and are analyzed as separate categories in the models that follow.

The second measure, parents' religious attendance, compares the religious practice of the respondents' two parents. Although the frequency of religious attendance is not an ideal cross-cultural measure of religious practice, it is the only measure of parents' religious practice in the 2008 ISSP Religion III Module. The ISSP asks respondents to indicate the frequency of their fathers' and mothers' religious attendance when the respondents were children. These items were measured using a 7-point index ranging from "Never" to "Several times a week." I recoded the religious attendance of both the respondents' fathers and mothers into three categories: "High" (at least once per month), "Low" (less than once per month), and "Never" (less than once per year). Then I created a new nominal variable with six religious attendance combinations of the respondents' parents: "High-High," "High-Low," "High-Never," "Low-Low," "Low-Never," and "Never-Never." For example, the category "High-Low" indicates that a respondent had one parent who attended at least once per month and one parent who attended less than once per month. The "High-High" category is the reference group.

\subsection{Sociodemographic Control Variables}

To control for other factors that might have a confounding influence on the association between the religiosity of the respondents and their parents, I include the following indicator variables: gender ( woman $=1$ ), university degree (university degree $=1$ ), marital status (married $=1$ ), and the presence of at least one child in the household (children in household $=1)^{5}$. The models also include indicator variables that control for urban and suburban locations with town/rural as the reference category. Age is a continuous measure ranging from 15-89 years. All respondents 89 years old or older were recoded into the 89 years old category because the U.S. survey pooled older respondents in this way. To account for non-linearities in the effect of age on religiosity, the models also include an age-squared term.

\subsection{Analytic Strategy}

To examine the associations between parental religious heterogamy and respondent religiosity, I test my hypotheses using fixed effects regression models. Because the aim of this study is to examine the effect of an individual-level characteristic (parental religious heterogamy) on an individual-level outcome (respondent religiosity), a fixed effects approach allows me to estimate this effect, while

5 The respondent may not necessarily be the parent of the child/children in the household. 
simultaneously controlling for all observed and unobserved country-level characteristics that might confound the relationship between parental religious heterogamy and respondent religiosity. Prior studies show that the economic, political, and social characteristics of a society impact processes of religious socialization (Kelley and Graaf 1997; Müller et al. 2014). Using fixed effects models, I can adjust for these and other national-level differences-such as political climate, social norms, or levels of religious tolerance- that may bias the estimates. In these analyses, I first estimate separate fixed effects models with controls for parents' religious marriage type (religious affiliation) and parents' religious attendance. Then, I estimate a model that includes both the parents' religious marriage type and parents' religious attendance to test whether parental attendance mediates the relationship between parents' religious marriage type and respondent religiosity.

\section{Results}

Descriptive statistics of all variables are shown in Table 1. About 83 percent of the final analysis sample ( $N=41,941$ individual respondents in 37 countries) had parents who shared the same religious affiliation, 4 percent had parents with two different affiliations, 6 percent had one unaffiliated parent, and 7 percent had two unaffiliated parents. About 22 percent of the sample reported having parents who attended religious services at different frequencies (High-Low, High-Never, Low-Never), while 45 percent reported having parents who both attended at least once per month (High-High). The final analysis sample is 55 percent women, 56 percent married, and 43 percent urban or suburban residents. Forty-two percent live in a household with children, 16 percent have a university degree, and the average age of respondents is about 46 years old.

Table 1. Descriptive statistics.

\begin{tabular}{|c|c|c|c|c|}
\hline Variables & Mean/Prop. & SD & Min. & Max. \\
\hline \multicolumn{5}{|l|}{ Dependent Variable } \\
\hline Overall Religiosity Score & 0.00 & 1.00 & -2.00 & 1.58 \\
\hline \multicolumn{5}{|l|}{ Independent Variables } \\
\hline \multicolumn{5}{|l|}{ Parents' Religious Marriage Type } \\
\hline Same Religion * & 0.83 & & 0 & 1 \\
\hline Mixed Religion & 0.04 & & 0 & 1 \\
\hline One Unaffiliated & 0.06 & & 0 & 1 \\
\hline Both Unaffiliated & 0.07 & & 0 & 1 \\
\hline \multicolumn{5}{|l|}{ Parents' Religious Attendance } \\
\hline Never-Never & 0.17 & & 0 & 1 \\
\hline Low-Never & 0.07 & & 0 & 1 \\
\hline Low-Low & 0.16 & & 0 & 1 \\
\hline High-Never & 0.06 & & 0 & 1 \\
\hline High-Low & 0.09 & & 0 & 1 \\
\hline High-High * & 0.45 & & 0 & 1 \\
\hline \multicolumn{5}{|l|}{ Sociodemographic Controls } \\
\hline Age & 45.96 & 17.07 & 15.00 & 89.00 \\
\hline University Degree & 0.16 & & 0 & 1 \\
\hline Woman & 0.55 & & 0 & 1 \\
\hline Married & 0.56 & & 0 & 1 \\
\hline Has Children in Household & 0.42 & & 0 & 1 \\
\hline \multicolumn{5}{|l|}{ Location } \\
\hline Urban & 0.30 & & 0 & 1 \\
\hline Suburban & 0.13 & & 0 & 1 \\
\hline Town/Rural * & 0.58 & & 0 & 1 \\
\hline
\end{tabular}

Table 2 presents the results of the fixed effects regression models of respondent religiosity, adjusting for both individual-level control variables and all potential observed and unobserved 
national-level confounders. Consistent with Hypotheses 1 and 2, Model 1 indicates that respondents with religiously heterogamous parents during childhood score significantly lower on the overall religiosity scale than respondents with religiously homogamous parents. Individuals with mixed religion parents $(b=-0.104)$ and one unaffiliated parent $(b=-0.404)$ are less religious than individuals with parents who had the same religious affiliation (both $p<0.001$ ). Model 1 also suggests that having one unaffiliated parent is associated with significantly lower levels of religiosity than having mixed religion parents. Supporting Hypothesis 3, supplementary analyses (not shown) confirm this pattern $(p<0.001)$. Figure 3, which presents predicted values on the religiosity scale for individuals with each parental marriage type, illustrates these relationships. Respondents with mixed religion parents have average levels of religiosity, while respondents with one unaffiliated parent have significantly below- $\mathrm{z}$ levels of religiosity.

Table 2. Results from fixed effects regression models predicting respondent religiosity.

\begin{tabular}{|c|c|c|c|c|c|c|}
\hline \multirow[t]{2}{*}{ Variable } & \multicolumn{2}{|l|}{1} & \multicolumn{2}{|c|}{2} & \multicolumn{2}{|l|}{3} \\
\hline & $b$ & SE & $b$ & SE & $b$ & SE \\
\hline \multicolumn{7}{|c|}{ Parents' Religious Marriage Type } \\
\hline Mixed Religion & $-0.104^{* * *}$ & $(0.019)$ & & & 0.028 & $(0.018)$ \\
\hline One Unaffiliated & $-0.404 * * *$ & $(0.016)$ & & & $-0.125^{* * *}$ & $(0.016)$ \\
\hline Both Unaffiliated & $-0.817^{* * *}$ & $(0.016)$ & & & $-0.329^{* * *}$ & $(0.017)$ \\
\hline \multicolumn{7}{|l|}{ Parents' Religious Attendance } \\
\hline Never-Never & & & $-1.063 * * *$ & $(0.011)$ & $-0.961^{* * *}$ & $(0.012)$ \\
\hline Low-Never & & & $-0.756^{* * *}$ & $(0.015)$ & $-0.728^{* * *}$ & $(0.016)$ \\
\hline Low-Low & & & $-0.531 * * *$ & $(0.011)$ & $-0.525^{* * *}$ & $(0.011)$ \\
\hline High-Never & & & $-0.460 * * *$ & $(0.016)$ & $-0.429^{* * *}$ & $(0.017)$ \\
\hline High-Low & & & $-0.250 * * *$ & $(0.013)$ & $-0.250 * * *$ & $(0.013)$ \\
\hline \multicolumn{7}{|l|}{ Sociodemographic Controls } \\
\hline Age & $-0.006^{* * *}$ & $(0.001)$ & $-0.005^{* * *}$ & $(0.001)$ & $-0.005^{* * *}$ & $(0.001)$ \\
\hline Age $^{2}$ & $0.000 * * *$ & $(0.000)$ & $0.000^{* * *}$ & $(0.000)$ & $0.000^{* * *}$ & $(0.000)$ \\
\hline University Degree & $-0.045^{* * *}$ & $(0.011)$ & $-0.067^{* * *}$ & $(0.010)$ & $-0.063^{* * *}$ & $(0.010)$ \\
\hline Woman & $0.280^{* * *}$ & (0.008) & $0.285^{* * *}$ & $(0.007)$ & $0.283^{* * *}$ & $(0.007)$ \\
\hline Married & $0.113^{* * *}$ & $(0.009)$ & $0.097^{* * *}$ & $(0.008)$ & $0.096^{* * *}$ & (0.008) \\
\hline Children in Household & $0.065^{* * *}$ & $(0.009)$ & $0.064^{* * *}$ & $(0.008)$ & $0.064^{* * *}$ & $(0.008)$ \\
\hline Urban & $-0.099 * * *$ & $(0.009)$ & $-0.075^{* * *}$ & $(0.009)$ & $-0.073^{* * *}$ & $(0.009)$ \\
\hline Suburban & $-0.065^{* * *}$ & $(0.012)$ & $-0.051 * * *$ & $(0.011)$ & $-0.046^{* * *}$ & $(0.011)$ \\
\hline Constant & $-0.210^{* * *}$ & $(0.029)$ & $0.076^{* *}$ & $(0.028)$ & $0.098^{* * *}$ & $(0.028)$ \\
\hline$R^{2}$ & \multicolumn{2}{|c|}{0.142} & \multicolumn{2}{|c|}{0.255} & \multicolumn{2}{|c|}{0.262} \\
\hline
\end{tabular}

Model 2 shows that dissimilarity in parents' attendance patterns also has a significant negative effect on respondent religiosity, adjusting for individual-level factors and all observed and unobserved national-level confounders. Respondents whose parents had High-Low $(b=-0.250)$, High-Never $(b=-0.460)$, and Low-Never $(b=-0.756)$ attendance patterns are significantly less religious overall than respondents whose two parents both attended religious services at least once a month (High-High; all $p<0.001$ ). Supplementary analyses (not shown) confirm that respondents whose parents had a Low-Never attendance pattern are significantly less religious than respondents whose parents had a Low-Low attendance pattern $(p<0.001)$. Respondents, however, with only one parent who attended once per month (High-Low, High-Never) are more religious overall than respondents whose parents both attended but less than once per month (Low-Low; both $p<0.001$ ). Figure 4 shows the predicted values of respondent religiosity for each pattern of parents' religious attendance. Consistent with Hypothesis 4, having only one parent who attends at least once a month is associated with lower respondent religiosity than having two parents who attend at least once a month, and having only one parent who attends more than once per year is associated with lower respondent religiosity than having two parents who attend more than once per year. 


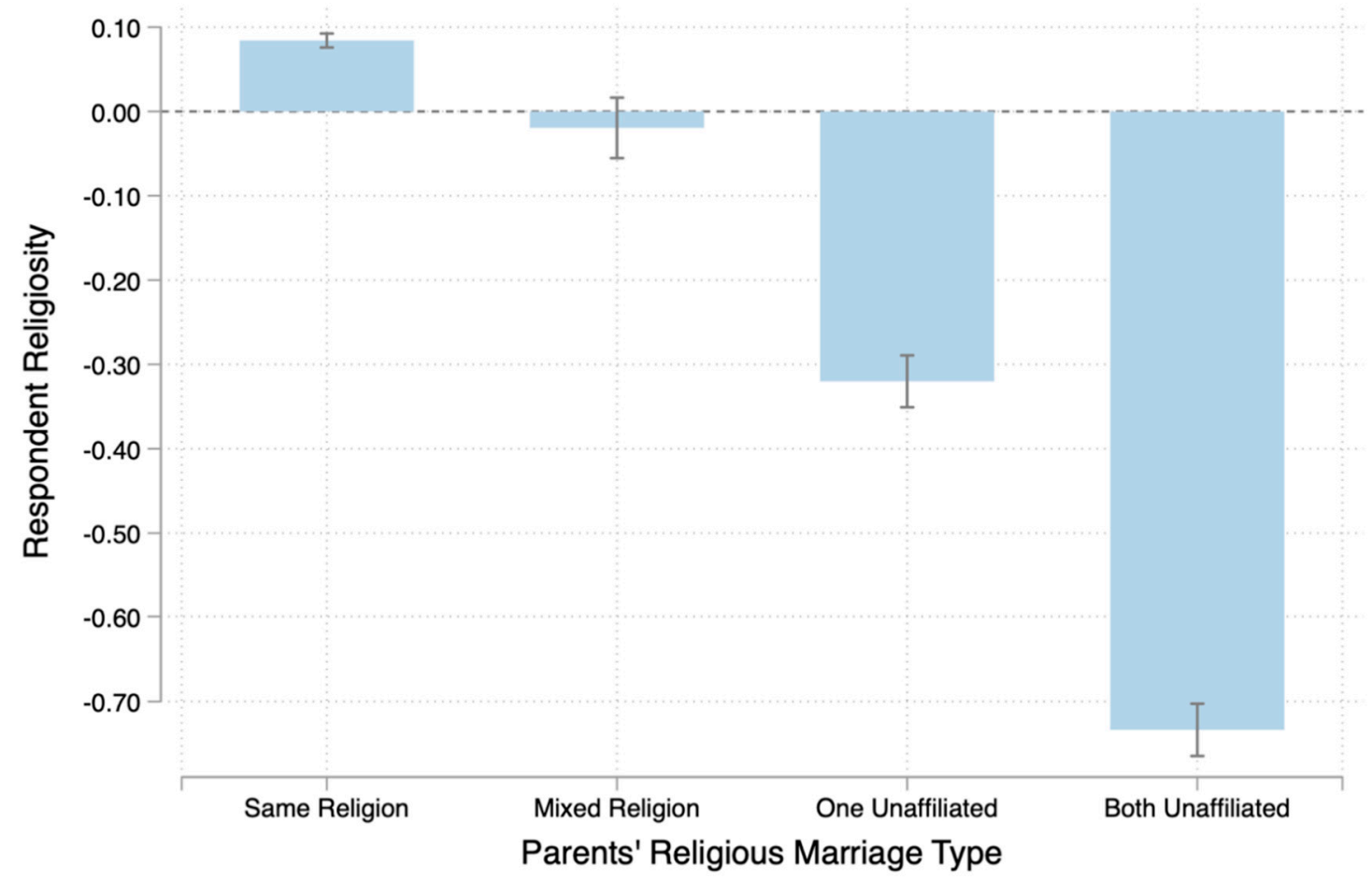

Figure 3. Predicted values of respondent religiosity by parents' religious affiliation combination. Values less than 0 indicate below-average respondent religiosity.

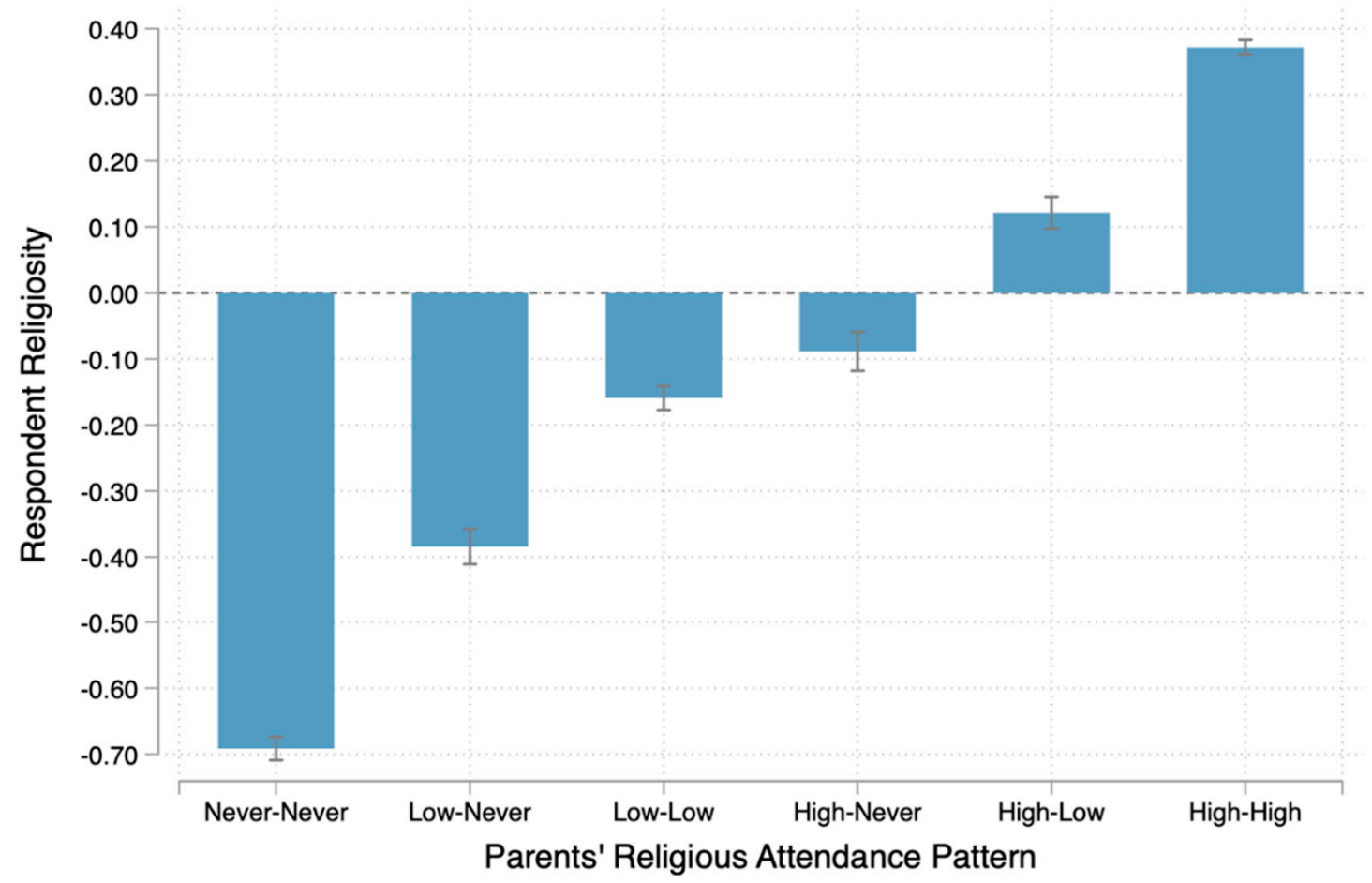

Figure 4. Predicted values of respondent religiosity by parents' religious attendance pattern. Values less than 0 indicate below-average respondent religiosity.

Results assessing whether parents' religious attendance patterns mediate the effect of parents' religious affiliation on the overall religiosity of the respondents are presented in Model 3. Separate tests for mediation indicate support for Hypothesis 5, confirming that parents' religious attendance fully 
mediates the negative effect of having parents with two different religious affiliations on respondent religiosity and partially mediates the negative effect of having one unaffiliated parent on respondent religiosity (both $p<0.001$ ). Figure 5 illustrates that after accounting for parents' religious attendance levels there is no statistical difference in the religiosity levels of respondents with same religion parents and mixed religion parents. Both are associated with above-average levels of religiosity. Having parents with two different religious affiliations is only indirectly associated with lower levels of religiosity as this association is attributable to lower levels of religious attendance among parents who have two different religions. However, as Figure 5 also shows, having one unaffiliated parent is still associated with lower levels of religiosity even when adjusting for parents' levels of religious attendance. Parental religious attendance only partially accounts for the difference in religiosity between respondents with parents of the same religion and respondents with one unaffiliated parent.

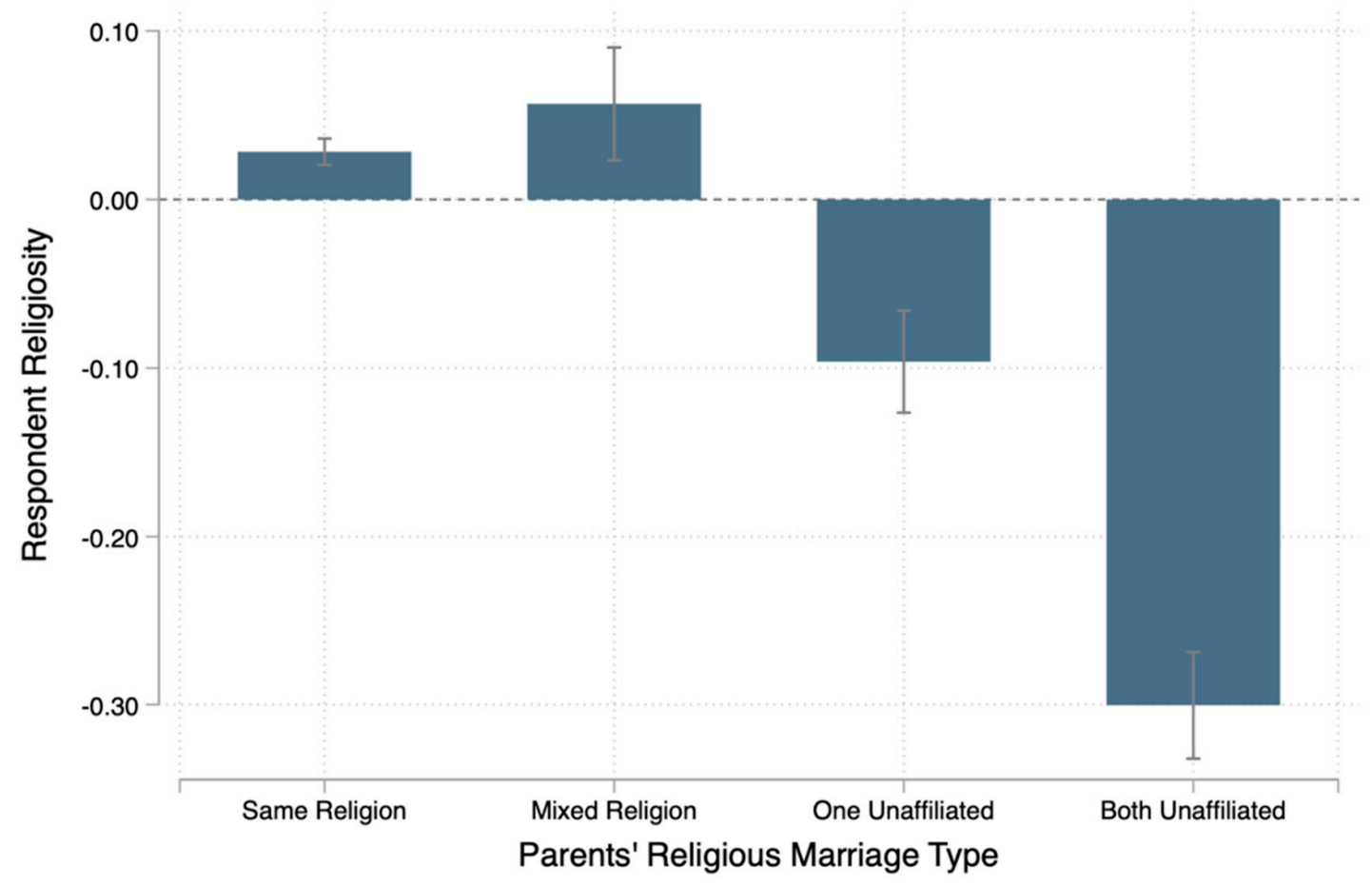

Figure 5. Predicted values of respondent religiosity by parents' religious affiliation combination adjusted for parents' religious attendance. Values less than 0 indicate below-average respondent religiosity.

\section{Discussion and Conclusions}

Using cross-national data from the 2008 ISSP Religion III Module, this study examined the effect of religious heterogamy on the intergenerational transmission of religion. Results confirm prior research (Hoge and Petrillo 1978; Nelsen 1990; Myers 1996; Bengtson 2013) but extend our understanding of religious socialization processes by demonstrating that the negative association between having interreligious parents during childhood and levels of religiosity in adulthood is independent of national-level factors. Using fixed effects regression models, which adjust for country-level contextual factors, these analyses provide evidence that having parents who do not share the same religious affiliation is associated with lower overall religiosity in individuals across a variety of social contexts (Kelley and Graaf 1997; Müller et al. 2014). Prior studies on the association between parental religious heterogamy and personal religiosity have been limited to predominantly Christian societies in the West. The present study has demonstrated that the negative association found in previous research is not an exclusively Western phenomenon but is independent of societal context. These analyses find a clear pattern that cannot be accounted for by contextual differences (i.e., social, economic, political, cultural) between respondents. Individuals with parents who identify with two different religions are less religious as adults than individuals with parents who identify with the same religion, and individuals 
with one unaffiliated parent are less religious than individuals with parents who identify with two different religions. Consistent with the religious socialization literature, this finding highlights the strength of the influence that parents have on the later religiosity of their children. Two parents who share the same religion are more effective at transmitting religion to their children than parents who have different religions.

This study has also demonstrated that parents' religious attendance mediates the relationship between parental religious heterogamy and lower levels of adult religiosity. In agreement with prior studies on the religiosity of interreligious couples (Petersen 1986; Williams and Lawler 2002; Petts and Knoester 2007; Pew Research Center 2016) and the importance of parents' religious activity on religious inheritance (Hunsberger and Brown 1984; Willits and Crider 1989; Myers 1996; Bengtson et al. 2009; Smith and Denton 2009; Bengtson 2013; Petts 2015), the results from this study indicate that individuals whose parents identify with two different religions are less religious because their parents attend religious services less frequently. Religious attendance also partially accounts for lower religiosity among individuals who had one unaffiliated parent during childhood. This finding supports the explanation of social learning theory that children learn religion by imitating the behavior modeled by their parents (Bandura and Walters 1977). Because interreligious parents participate in religion less frequently, they model religion less intensely for their children.

This study also has important implications for anticipating and understanding changes in the religious landscapes of societies characterized by religious diversity and increasing levels of religious heterogamy. Researchers have identified the effectiveness of one generation to reproduce religion in the next generation as a major factor in the growth or decline of religion in a society (Voas 2003; Bisin et al. 2004; Bengtson et al. 2009; Bengtson 2013). Numerous social factors such as parents' religiosity, parents' education, quality of family relationships, family structures, the role of grandparents, and participation in religious communities affect the reproduction of religion across generations (Myers 1996; Bengtson 2013). As this study demonstrates, parental religious heterogamy and dissimilarity in religious participation are additional factors that significantly impact the transmission of religion from parents to children. As the number of interreligious marriages changes in a given society, we can anticipate generational changes in the overall religious characteristics of that society. As we try to better understand the determinants and trends of religiosity in society, more attention should be paid to the role of families and the social factors that influence religious inheritance.

Several important limitations to this study warrant mention. First, these analyses were constrained to using self-identification as religious, belief in God, and the frequencies of religious attendance and prayer to measure religiosity. Because these conventional measures may not adequately capture the religiosities of individuals in non-Abrahamic faiths, non-Western contexts, or interreligious families (Traphagan 2005; Arweck and Nesbitt 2010; Seamon 2012; Tanaka 2010; Chao and Yang 2018), improved measures are needed for future studies of religiously diverse populations. For interreligious families in particular, what is interpreted as "less" religious on these conventional religiosity measures might be better understood as "differently" religious. Field studies exploring the complexities of religious life in religious intermarriages have argued that the terms religious transformation and multiculturalism more accurately characterize these families, who are believed to be representative of broader changes in the religious environments of religiously diverse societies (Arweck and Nesbitt 2010; Seamon 2012).

Second, societies that are not predominantly Christian and societies from Asia, Africa, and South America are underrepresented in the ISSP data set. Although the findings here suggest that religious heterogamy impacts religious socialization in similar ways across societies, more research is needed to better understand processes of religious inheritance in regions outside of Europe and North America and in regions where Christianity is not the dominant religion. Data for additional countries would provide stronger support for the findings presented here.

Third, the ISSP 2008 dataset includes little information about respondents' parents or about other characteristics of the respondents' families. Religious socialization literature proposes numerous family characteristics that affect the transmission of religion from parents to children (Myers 1996; Bengtson 2013). 
For example, prior findings show that parents' marital stability significantly weakens the transmission of religion to children (Zhai et al. 2007; Ellison et al. 2011; Uecker and Ellison 2012) and that religiously heterogamous marriages are less stable than religiously homogamous marriages (Heaton and Pratt 1990; Lehrer and Chiswick 1993; Call and Heaton 1997; Kalmijn et al. 2005; Wright et al. 2017). Information about parents' marital status and other family characteristics was not available in the 2008 ISSP dataset but should be included in future studies as important confounders.

Despite these limitations, the current study contributes to our understanding of the relationship between religious heterogamy and the intergenerational transmission of religion. Although previous research has demonstrated the negative association between having interreligious parents and an individual's religiosity, this study is the first to examine whether this relationship is independent of national-level social, political, or economic factors and, therefore, generalizable across societies. The findings presented here not only indicate that religiously heterogamous parents produce weaker religious socialization outcomes than religiously homogamous parents but also that this relationship exists across nations and is independent of contextual factors. Evidence also suggests that lower levels of parental religious attendance fully account for this difference when each parent identifies with a different religion. Future research should further explore the mechanisms (i.e., modeling, channeling, affective bonds) of parents' religious influence on their children, how these mechanisms are impacted by religious heterogamy, and how these relationships might differ across societies and religious groups.

Funding: This research received no external funding.

Conflicts of Interest: The author declares no conflict of interest.

\section{References}

Anders, Sarah F. 1955. Religious Behavior of Church Families. Marriage and Family Living 17: 54-57. [CrossRef]

Arweck, Elisabeth, and Eleanor Nesbitt. 2010. Plurality at Close Quarters: Mixed-Faith Families in the UK. Journal of Religion in Europe 3: 155-82. [CrossRef]

Bandura, Albert, and Richard H. Walters. 1977. Social Learning Theory. Upper Saddle River: Prentice-Hall.

Bengtson, Vern L. 2013. Families and Faith: How Religion Is Passed down across Generations. Oxford: Oxford University Press.

Bengtson, Vern L., Timothy J. Biblarz, and Robert E. L. Roberts. 2002. How Families Still Matter: A Longitudinal Study of Youth in Two Generations. Cambridge: Cambridge University Press.

Bengtson, Vern L., Casey E. Copen, Norella M. Putney, and Merril Silverstein. 2009. A Longitudinal Study of the Intergenerational Transmission of Religion. International Sociology 24: 325-45. [CrossRef]

Bisin, Alberto, Giorgio Topa, and Thierry Verdier. 2004. Religious Intermarriage and Socialization in the United States. Journal of Political Economy 112: 615-64. [CrossRef]

Call, Vaughn R. A., and Tim B. Heaton. 1997. Religious Influence on Marital Stability. Journal for the Scientific Study of Religion 36: 382-92. [CrossRef]

Chao, L. Luke, and Fenggang Yang. 2018. Measuring Religiosity in a Religiously Diverse Society: The China Case. Social Science Research 74: 187-95. [CrossRef] [PubMed]

Chaves, Mark. 1991. Family Structure and Protestant Church Attendance: The Sociological Basis of Cohort and Age Effects. Journal for the Scientific Study of Religion 30: 501-14. [CrossRef]

Chinitz, Joshua G., and Robert A. Brown. 2001. Religious Homogamy, Marital Conflict, and Stability in Same-Faith and Interfaith Jewish Marriages. Journal for the Scientific Study of Religion 40: 723-33. [CrossRef]

Clark, Cynthia A., and Everett L. Worthington. 1990. Family Variables Affecting the Transmission of Religious Values from Parents to Adolescents: A Review. Lanham: University Press of America.

Copen, Casey, and Merril Silverstein. 2007. Transmission of Religious Beliefs Across Generations: Do Grandparents Matter? Journal of Comparative Family Studies 38: 497-510.

Cornwall, Marie. 1989. The Determinants of Religious Behavior: A Theoretical Model and Empirical Test. Social Forces 68: 572-92. [CrossRef]

Curtis, Kristen Taylor, and Christopher G. Ellison. 2002. Religious Heterogamy and Marital Conflict: Findings from the National Survey of Families and Households. Journal of Family Issues 23: 551-76. [CrossRef] 
Denton, Melinda Lundquist, and Julian Culver. 2015. Family Disruption and Racial Variation in Adolescent and Emerging Adult Religiosity. Sociology of Religion; Washington 76: 222-39. [CrossRef]

Ellison, Christopher G., and Darren E. Sherkat. 1999. Identifying the Semi-Involuntary Institution: A Clarification. Social Forces 78: 793-802. [CrossRef]

Ellison, Christopher G., Anthony B. Walker, Norval D. Glenn, and Elizabeth Marquardt. 2011. The Effects of Parental Marital Discord and Divorce on the Religious and Spiritual Lives of Young Adults. Social Science Research 40: 538-51. [CrossRef]

Erickson, Joseph A. 1992. Adolescent Religious Development and Commitment: A Structural Equation Model of the Role of Family, Peer Group, and Educational Influences. Journal for the Scientific Study of Religion 31: 131-52. [CrossRef]

Glass, Jennifer, Vern L. Bengtson, and Charlotte Chorn Dunham. 1986. Attitude Similarity in Three-Generation Families: Socialization, Status Inheritance, or Reciprocal Influence? American Sociological Review 51: 685-98. [CrossRef]

Glenn, Norval D. 1982. Interreligious Marriage in the United States: Patterns and Recent Trends. Journal of Marriage and Family 44: 555-66. [CrossRef]

Havens, Joseph. 1964. A Study of Religious Conflict in College Students. The Journal of Social Psychology 64: 77-87. [CrossRef] [PubMed]

Heaton, Tim B. 1984. Religious Homogamy and Marital Satisfaction Reconsidered. Journal of Marriage and the Family 46: 729-33. [CrossRef]

Heaton, Tim B., and Edith L. Pratt. 1990. The Effects of Religious Homogamy on Marital Satisfaction and Stability. Journal of Family Issues 11: 191-207. [CrossRef]

Himmelfarb, Harold S. 1980. The Study of American Jewish Identification: How It Is Defined, Measured, Obtained, Sustained and Lost. Journal for the Scientific Study of Religion 19: 48-60. [CrossRef]

Hoge, Dean R., and Gregory H. Petrillo. 1978. Determinants of Church Participation and Attitudes Among High School Youth. Journal for the Scientific Study of Religion 17: 359-79. [CrossRef]

Hoge, Dean R., Benton Johnson, and Donald A. Luidens. 1994. Vanishing Boundaries: The Religion of Mainline Protestant Baby Boomers. Louisville: Westminster/John Knox Press.

Hunsberger, Bruce, and Laurence B. Brown. 1984. Religious Socialization, Apostasy, and the Impact of Family Background. Journal for the Scientific Study of Religion 23: 239-51. [CrossRef]

ISSP Research Group. 2012. International Social Survey Programme 2008: Religion III (ISSP 2008). ZA4950 No. Data File Version 2.2.0. Cologne: GESIS Data Archive.

Kalmijn, Matthijs. 1991. Shifting Boundaries: Trends in Religious and Educational Homogamy. American Sociological Review 56: 786-800. [CrossRef]

Kalmijn, Matthijs, Paul M. De Graaf, and Jacques P. G. Janssen. 2005. Intermarriage and the Risk of Divorce in The Netherlands: The Effects of Differences in Religion and in Nationality, 197494. Population Studies 59: 71-85. [CrossRef] [PubMed]

Kelley, Jonathan, and Nan Dirk De Graaf. 1997. National Context, Parental Socialization, and Religious Belief: Results from 15 Nations. American Sociological Review 62: 639-59. [CrossRef]

Lawton, Leora E., and Regina Bures. 2001. Parental Divorce and the "Switching" of Religious Identity. Journal for the Scientific Study of Religion 40: 99-111. [CrossRef]

Lehrer, Evelyn L. 1998. Religious Intermarriage in the United States: Determinants and Trends. Social Science Research 27: 245-63. [CrossRef]

Lehrer, Evelyn L., and Carmel U. Chiswick. 1993. Religion as a Determinant of Marital Stability. Demography 30: 385-404. [CrossRef]

Mahoney, Annette. 2010. Religion in Families, 1999-2009: A Relational Spirituality Framework. Journal of Marriage and Family 72: 805-27. [CrossRef]

Martin, Todd F., James M. White, and Daniel Perlman. 2003. Religious Socialization: A Test of the Channeling Hypothesis of Parental Influence on Adolescent Faith Maturity. Journal of Adolescent Research 18: 169-87. [CrossRef]

McCutcheon, Allan L. 1988. Denominations and Religious Intermarriage: Trends Among White Americans in the Twentieth Century. Review of Religious Research 29: 213-27. [CrossRef] 
Müller, Tim S., Nan Dirk De Graaf, and Peter Schmidt. 2014. Which Societies Provide a Strong Religious Socialization Context? Explanations Beyond the Effects of National Religiosity. Journal for the Scientific Study of Religion 53: 739-59. [CrossRef]

Myers, Scott M. 1996. An Interactive Model of Religiosity Inheritance: The Importance of Family Context. American Sociological Review 61: 858-66. [CrossRef]

Nelsen, Hart M. 1990. The Religious Identification of Children of Interfaith Marriages. Review of Religious Research 32: 122-34. [CrossRef]

O'Leary, Richard. 2001. Modernization and Religious Intermarriage in the Republic of Ireland. The British Journal of Sociology 52: 647-65. [CrossRef]

Petersen, Larry R. 1986. Interfaith Marriage and Religious Commitment Among Catholics. Journal of Marriage and Family 48: 725-35. [CrossRef]

Petts, Richard J. 2015. Parental Religiosity and Youth Religiosity: Variations by Family Structure. Sociology of Religion 76: 95-120. [CrossRef]

Petts, Richard J., and Chris Knoester. 2007. Parents' Religious Heterogamy and Children's Well-Being. Journal for the Scientific Study of Religion 46: 373-89. [CrossRef]

Pew Research Center. 2016. One-in-Five U.S. Adults Were Raised in Interfaith Homes. Washington: Pew Research Center.

Putnam, Robert D., and David E. Campbell. 2010. American Grace: How Religion Divides and Unites US. New York: Simon and Schuster.

Putney, Snell, and Russell Middleton. 1961. Rebellion, Conformity, and Parental Religious Ideologies. Sociometry 24: 125-35. [CrossRef]

Regnerus, Mark D., Christian Smith, and Brad Smith. 2004. Social Context in the Development of Adolescent Religiosity. Applied Developmental Science 8: 27-38. [CrossRef]

Roof, Wade Clark, and Dean R. Hoge. 1980. Church Involvement in America: Social Factors Affecting Membership and Participation. Review of Religious Research 21: 405-26. [CrossRef]

Rosenfeld, Michael J. 2008. Racial, Educational and Religious Endogamy in the United States: A Comparative Historical Perspective. Social Forces 87: 1-31. [CrossRef]

Schwadel, Philip. 2015. Explaining Cross-National Variation in the Effect of Higher Education on Religiosity. Journal for the Scientific Study of Religion 54: 402-18. [CrossRef]

Seamon, Erika B. 2012. Interfaith Marriage in America: The Transformation of Religion and Christianity. New York: Palgrave Macmillan.

Sherkat, Darren E. 1991. Leaving the Faith: Testing Theories of Religious Switching Using Survival Models. Social Science Research 20: 171-87. [CrossRef]

Sherkat, Darren E. 1998. Counterculture or Continuity? Competing Influences on Baby Boomers' Religious Orientations and Participation. Social Forces 76: 1087-14. [CrossRef]

Sherkat, Darren E. 2004. Religious Intermarriage in the United States: Trends, Patterns, and Predictors. Social Science Research 33: 606-25. [CrossRef]

Smith, Christian, and Melinda Lundquist Denton. 2009. Soul Searching: The Religious and Spiritual Lives of American Teenagers. New York: Oxford University Press.

Stolzenberg, Ross M., Mary Blair-Loy, and Linda J. Waite. 1995. Religious Participation in Early Adulthood: Age and Family Life Cycle Effects on Church Membership. American Sociological Review 60: 84-103. [CrossRef]

Tanaka, Kimiko. 2010. Limitations for Measuring Religion in a Different Cultural Context: The Case of Japan. The Social Science Journal 47: 845-52. [CrossRef] [PubMed]

Traphagan, John W. 2005. Multidimensional Measurement of Religiousness/Spirituality for Use in Health Research in Cross-Cultural Perspective. Research on Aging 27: 387-419. [CrossRef]

Uecker, Jeremy E., and Christopher G. Ellison. 2012. Parental Divorce, Parental Religious Characteristics, and Religious Outcomes in Adulthood. Journal for the Scientific Study of Religion 51: 777-94. [CrossRef] [PubMed]

Vaaler, Margaret L., Christopher G. Ellison, and Daniel A. Powers. 2009. Religious Influences on the Risk of Marital Dissolution. Journal of Marriage and Family 71: 917-34. [CrossRef]

Voas, David. 2003. Intermarriage and the Demography of Secularization. The British Journal of Sociology 54: 83-108. [CrossRef] [PubMed] 
Wilcox, W. Bradford, and Nicholas H. Wolfinger. 2008. Living and Loving 'Decent': Religion and Relationship Quality Among Urban Parents. Social Science Research 37: 828-43. [CrossRef] [PubMed]

Williams, Lee M., and Michael G. Lawler. 2002. Religious Heterogamy and Religiosity: A Comparison of Interchurch and Same-Church Individuals. Journal for the Scientific Study of Religion 40: 465-78. [CrossRef]

Willits, Fern K., and Donald M. Crider. 1989. Church Attendance and Traditional Religious Beliefs in Adolescence and Young Adulthood: A Panel Study. Review of Religious Research 31: 68-81. [CrossRef]

Wilson, John, and Darren E. Sherkat. 1994. Returning to the Fold. Journal for the Scientific Study of Religion 33: 148-61. [CrossRef]

Wright, David M., Michael Rosato, and Dermot O'Reilly. 2017. Influence of Heterogamy by Religion on Risk of Marital Dissolution: A Cohort Study of 20,000 Couples. European Journal of Population 33: 87-107. [CrossRef]

Zhai, Jiexia Elisa, Christopher G. Ellison, Norval D. Glenn, and Elizabeth Marquardt. 2007. Parental Divorce and Religious Involvement Among Young Adults. Sociology of Religion 68: 125-44. [CrossRef]

C 2019 by the author. Licensee MDPI, Basel, Switzerland. This article is an open access article distributed under the terms and conditions of the Creative Commons Attribution (CC BY) license (http:// creativecommons.org/licenses/by/4.0/). 